\title{
Short Communication: The relationship between content of particular metabolites of fallen mangrove leaves and the rate at which the leaves decompose over time
}

\author{
DAFIT ARIYANTO ${ }^{1,2 v}$, DIETRIECH G. BENGEN ${ }^{2 v \vee}$, TRI PRARTONO ${ }^{2}$, YUSLI WARDIATNO ${ }^{3}$ \\ ${ }^{1}$ Department of Aquaculture, Faculty of Agriculture, Universitas Asahan. Jl. Jend. Ahmad Yani, Kisaran, Asahan 21216, North Sumatra, Indonesia \\ Tel./fax. +62-623-623-42643, `email: dafit_ariyanto@yahoo.com \\ ${ }^{2}$ Department of Marine Science and Technology, Faculty of Fisheries and Marine Science, Institut Pertanian Bogor. Jl. Agatis No. 1, Bogor 16680, West \\ Java, Indonesia. Tel./fax.+6- 251-8623644."vemail: dieter@indo.net.id \\ ${ }^{3}$ Department of Aquatic Resources Management, Faculty of Fisheries and Marine Science, Institut Pertanian Bogor. Jl. Agatis No. 1, Bogor 16680, West \\ Java, Indonesia
}

Manuscript received: 15 January 2018. Revision accepted: 5 April 2018.

\begin{abstract}
Ariyanto D, Bengen DG, Prartono T, Wardiatno Y. 2018. Short Communication: The relationship between content of particular metabolites of fallen mangrove leaves and the rate at which the leaves decompose over time. Biodiversitas 19: 780-785. Fallen mangrove leaves contain metabolites that play a role in their decomposition in coastal conditions. This research was conducted from September 2016 to February 2017 in Pasar Banggi, Rembang, Central Java, with the purpose of investigating the impact of the leaf metabolites of various mangrove species on the rate of decomposition of the leaves in exposed litter bags The results suggested that secondary metabolites are closely involved in the decomposition of the mangrove leaves. The fastest rate of decomposition was found in Avicennia marina, and the slowest in Rhizophora stylosa. The leaves of A. marina required 10 days (half-life, $\mathrm{t}_{50}$ ) to decompose by $50 \%$ and this was closely related to the phosphorus content of the leaves. On the other hand, $R$. stylosa required 24 days (half-life, $\mathrm{t}_{50}$ ) to decompose by $50 \%$.
\end{abstract}

Keywords: Decomposition, mangrove leaves, mass loss, Pasar Banggi coast, phosphorus, tannin

\section{INTRODUCTION}

The Pasar Banggi coast in Rembang, Central Java is fringed by various species of mangrove such as Rhizophora mucronata Lam., Rhizophora apiculata Blume, Rhizophora stylosa Griff., Avicennia marina (Forssk.) Vierh., and Sonneratia alba $\mathrm{Sm}$. Such mangrove biomass contains both primary and secondary metabolic constituents. Mangroves are recorded as producing 100,000 to 200,000 types of secondary metabolites (Ralston et al. 2005). Secondary metabolites produced by plants are organic compounds with bioactive effects. The secondary metabolites of mangroves are produced in varying amounts determined by both genetic and environmental influences (Covelo et al. 2011). The secondary metabolic compounds of mangroves are particularly rich within the leaves (Covelo et al. 2011). Types of secondary metabolites in mangroves include tannins, sugars, free amino acids, and proteins among others (Yan and Guizhu 2007, Takemura et al. 2000). Their concentrations vary according to vegetation type (Hernes dan Hedges 2004), growing phase (Lin et al. 2006), and environment conditions (Northup et al. 1998). Sea-soaked leaves of mangrove released sugars, proteins, polyphenols, and inorganic nutrients to the water environment in a relatively short time.

Mangrove forest is a carbon-rich ecosystem of the tropical regions. It is highly productive, and its leaf fall decomposes readily in the coastal environment.
Decomposition is an important phase in the nutrient cycles of mangrove ecosystems. Decrease in weight of fallen mangrove leaves due to decomposition requires time and depends on the degree of washing to which the leaves are exposed (Mfilinge et al. 2005). Mangrove leaves decompose at different times and rate. The decomposition process starts with simple physical and chemical changes (Imgraben and Ditmmann 2008) which a drive the carbon and nutrient cycles in the mangrove ecosystem (Holguin et al. 2001; Hessen et al. 2004; Norris et al. 2012). The time rate of decomposition varies according to three main factors; the condition of the environment, the community of decomposers, and the substrate quality (Castanho and de Oliveira 2008). Tide promotes the shedding of leaves and the rate of microbial decomposition (Boulton and Boon 1991). Due to the activity of decomposers and currents and other transport processes, nutrients such as nitrogen and phosphorus become available for primary producers and higher organisms in the food chain (Wardle et al. 2004).

The decomposing process can be assessed by measuring the weight decrease due to loss of materials such as sugars and tannin compounds (Davis et al. 2003; Kristensen et al. 2008). Kandil et al. (2004) reported that decomposition is affected by tannins that act as defenses against herbivores. The products of the decomposing process can be utilized and consumed by benthic organisms (gastropod) (Kursar and Coley 1991; Ariyanto et al. 2018). 
In the research described in this paper, we aimed to reveal the role of certain secondary metabolites in the decomposition of leaves of various mangrove species on the Pasar Banggi coast of Rembang, Central Java, Indonesia.

\section{MATERIALS AND METHODS}

\section{Study area}

This research was conducted from September 2016 to February 2017 along the Pasar Banggi coast, Rembang, Central Java, Indonesia (Figure 1). The sampling locations were five stations each with a different mangrove species: they were station 1 (Rhizophora mucronata); station 2 (Rhizophora apiculata); station 3 (Sonneratia alba); station 4 (Rhizophora stylosa); and station 5 (Avicennia marina). These stations were purposely selected to represent the typical mangrove population growing in each. Each station had three sub-stations.

\section{The measurement of leaf decomposition}

The rate of leaf decomposition at each station was measured for leaves freshly fallen from the mangrove trees. The decomposition rate was determined using the mesh bag technique with bags $16 \mathrm{~cm}$ by $21 \mathrm{~cm}$ in size and with a mesh size of $1 \mathrm{~mm}$. This mesh size was used to prohibit mesofauna accessing the bags and thus affecting the extent of apparent microbial decomposition. The bags were placed up on $30 \mathrm{~cm}$ of sediment to prohibit predators (Figure 1.A), and were suspended to avoid direct contact with the sediment bed and above the level of the sea-water flux and reflux (Figure 1.B). Mangrove leaves typical of the species at each station on the Pasar Banggi coast -namely, $R$. mucronata, $R$. apiculata, $R$. stylosa, $S$. alba, and A. marina -were placed in the mesh bags, i.e., $50 \mathrm{~g}$ of leaf in each bag.
Measurements of leaf dry weight in the bags were carried out on day 0 , day 30, and day 60. Rates of leaf decomposition were then determined using the formula of Ashton et al. (1999): $X_{t}=X_{0} e^{-k t}$. Where $X_{o}$ is the mass of the initial material, $X_{t}$ is the mass remaining after time $t$ (days) and $\mathrm{k}$ is a decay coefficient $\left(\right.$ days $^{-1}$ ). The half-life $\left(t_{50}\right)$ is the time required for half of the initial mass to decay away and is determined as $t_{50}=\ln 2 / \mathrm{K}$ ).

\section{The measurement of leaf metabolite content}

Before decomposition had started, collected leaves fresh from the field were divided into groups according to species of mangrove. For estimating metabolite content, the leaves were washed and then dried at $80^{\circ} \mathrm{C}$ temperature. The measurement of secondary metabolites was conducted in the Laboratory of Food Science and Technology in Bogor Agricultural University, Indonesia. The metabolites determined were tannins (Hagerman and Butler 1978), phosphorus (Anderson and Ingram 1989) and total sugar (Dubois et al. 1956) by using a spectrophotometer. Meanwhile, total amino acids were determined using used an HPLC (Moore and Stein 1948).

\section{Data analysis}

The relationship between the content of secondary metabolites in the various types of mangrove leaves and the rate of decomposition of the leaves was investigated by using Correspondence Analysis (CA). The analysis on row data matrix (mangrove species; decomposition rate) and column (metabolites content; tannins, total sugar, phosphorus, and total amino acids) purposed to discover the relationship between the metabolites compounds and decomposition rate of mangrove leaves). The analysis was conducted with XLstat 2016 software.

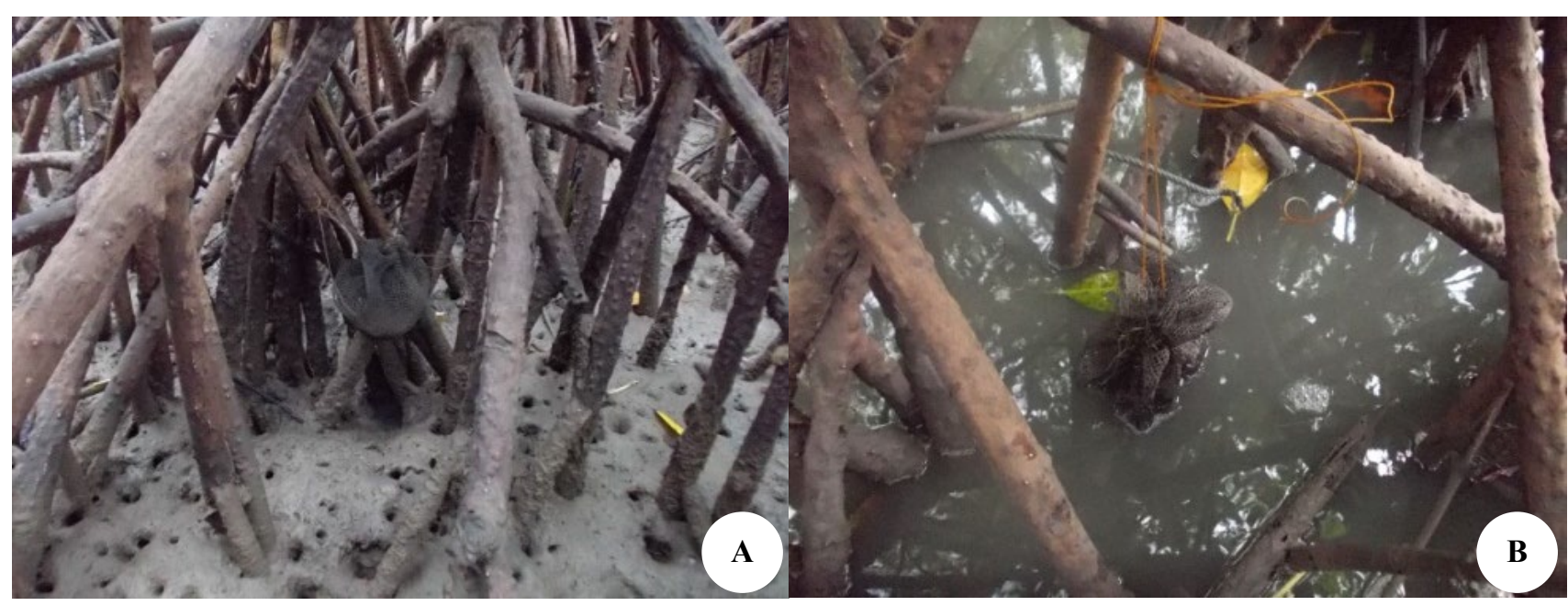

Figure 1. The decomposition measurement conditions at low tide (A) and high tide (B) 


\section{RESULTS AND DISCUSSION}

\section{Metabolite compounds}

The research showed that the five mangrove species varied in the tannin, total sugar and phosphorus contents of their leaves. Leaves of A. marina had the lowest content of tannin and S. alba leaves had the highest content of tannins out of the five species; leaves of $A$. marina had the highest and $R$. apiculata the lowest content of total sugars (Table 1). The total amino acid content of mangrove leaves on the Banggi Coast was 4.52 to $5.55 \mathrm{mg} / \mathrm{g}$. R. mucronata leaves contained the lowest content of amino acid out of the five mangrove species. The amino acid content of the leaves in our study ranged from highest to lowest as follows: $R$. apiculata $>A$. marina $>R$. stylosa $>S$. alba $>R$. mucronata.

\section{Decomposition of leaves over time}

The dry weight of the leaves in the mesh bags declined by $31-100 \%$ over the research period of 60 days (Figure 2 ). Observation after 30 days showed that leaves of $S$. alba had experienced the slowest rate of decomposition, having declined in dry weight from $50 \mathrm{~g}$ to $35.6 \pm 9.9 \mathrm{~g}$; while leaves of A. marina had experienced the steepest decline in dry weight, down to $6.3 \pm 2.3 \mathrm{~g}$ at day 30 . Observation after 60 days showed that leaves of $A$. marina had experienced the greatest decline in dry weight during the decomposing process, with $0 \mathrm{~g}$ remaining in the mesh bags; while $R$. stylosa had experienced the least decline in weight, down to $9.5 \pm 2.8 \mathrm{~g}$ at day 60 . At day 60 , the decline in leaf dry weight, ranked from greatest decline to least, was as follows: A. marina $>S$. alba $>R$. mucronata $>R$. apiculata $>$ R. stylosa.

There were observed physical differences between the mangrove leaves samples placed in the bags. Leaves of $A$. marina were observed to be the thinnest of the mangrove species compared in this study. This was probably an important factor in their high rate of decomposition. Observation suggested that the thicker the leaves were the slower was the extent of decomposition over the 60 day period.

Calculation of the decomposition rate constant $(\mathrm{k})$ revealed differences between the species; the values for $\mathrm{k}$ varied from 0.028 to 0.065 across the species (Table 2). The $\mathrm{k}$ value $(0.028)$ for $S$. alba was the lowest which indicated that $S$. alba had the slowest rate of leaf decomposition of the five species. Therefore it required longer time than the others to decompose. Meanwhile, $R$. stylos $a$ and $R$. apiculata have the constant value of 0.079 and 0.041 , higher than the others. For A. marina there was a more rapid initial rate of decomposition with the weight of remaining leaf falling close to zero well before the $60^{\text {th }}$ day. The decomposition rate constant for the species ranked from highest to lowest as follows A. marina $>S$. alba $>$ R. apiculata $>$ R. mucronata $>$ R. stylosa.

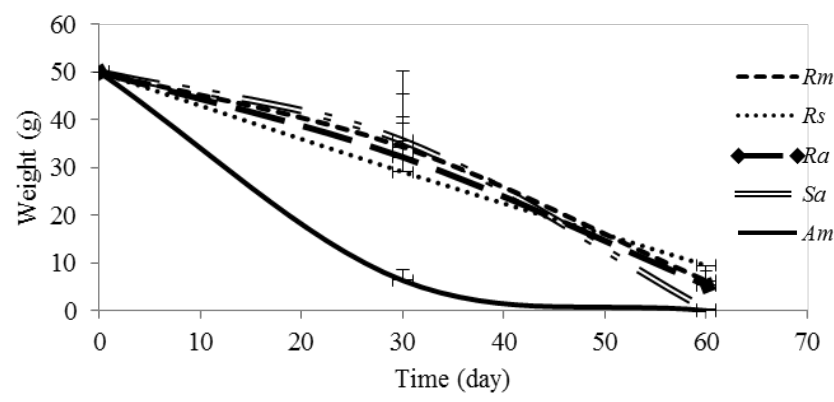

Figure 2. Decomposition in mangrove leaves on the Pasar Banggi Coast of Rembang, Central Java, Indonesia. Note: $\mathrm{Rm}=$ Rhizophora mucronata, $\mathrm{Rs}=$ Rhizophora stylosa $\mathrm{R}=$ Rhizophora apiculata, $\mathrm{Sa}=$ Sonneratia alba, Am = Avicennia marina

Table 1. The content of tannin, phosphorus, total sugar, and total amino acids in leaves of various species of mangrove on the Pasar Banggi coast of Rembang, Central Java, Indonesia

\begin{tabular}{|c|c|c|c|c|c|c|c|c|}
\hline \multirow[t]{2}{*}{ Mangrove sp. } & \multicolumn{2}{|c|}{ Tannin (mg/g) } & \multicolumn{2}{|c|}{ Total sugar (mg/g) } & \multicolumn{2}{|c|}{ Phosphorus (mg/g) } & \multicolumn{2}{|c|}{ Amino acid (mg/g) } \\
\hline & Study & Comparison & Study & Comparison & Study & Comparison & Study & Comparison \\
\hline R. mucronata & 4.39 & $1.231-5.71^{\mathrm{a}}$ & 0.44 & $0.06-1.231^{\mathrm{a}}$ & 17.08 & $0.98-4.93^{\mathrm{a}}$ & 4.52 & $5.71-9.49^{\mathrm{a}}$ \\
\hline R. apiculata & 1.07 & $0.4-1.23^{b}$ & 0.35 & $0.3^{\mathrm{e}}$ & 4.64 & $7.12 \mathrm{~h}$ & 6.05 & $3.21 ; 1.4^{\mathrm{e}}$ \\
\hline R. stylosa & 2.69 & $9.32-9.74^{c}$ & 0.52 & $0.04-0.06^{f}$ & 9.36 & $4.82 \pm 2.09^{\mathrm{i}}$ & 5.42 & $1.9^{\mathrm{k}}$ \\
\hline S. alba & 7.09 & $7.60-8.17^{\mathrm{c}}$ & 0.85 & $0.05-11^{\mathrm{f}}$ & 15.12 & $6^{\mathrm{j}}$ & 5.21 & $4.7^{\mathrm{k}} ; 1^{1}$ \\
\hline A.marina & 0.85 & $3.73^{\mathrm{d}}$ & 0.9 & $0.85-0.99 ; 0.5 \mathrm{~g}, \mathrm{e}$ & 27.18 & $31.71 \pm 6.56^{\mathrm{d}}$ & 5.55 & $1,9^{\mathrm{k}} 1.5^{\mathrm{e}}$ \\
\hline
\end{tabular}

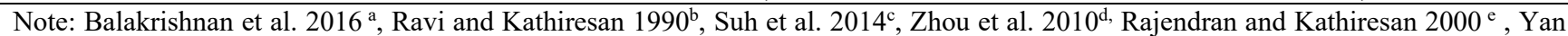
and Guizhu $2007^{\mathrm{f}}$, Fukushima et al. $1997^{\mathrm{g}}$, Gong and Ong $1990^{\mathrm{h}}$, Lin and Wang 2001 ${ }^{\mathrm{i}}$, Telave $2015^{\mathrm{j}}$, Popp et al. 1983 ${ }^{\mathrm{k}}$, Telave $2015^{\mathrm{l}}$

Table 2. Value of decomposition rate constant (k) for mangrove leaves on the Pasar Banggi coast of Rembang, Central Java, Indonesia.

\begin{tabular}{lccccccl}
\hline \multirow{2}{*}{ Mangrove } & \multicolumn{3}{c}{ Present study } & \multicolumn{2}{c}{ Comparison study } \\
\cline { 2 - 7 } & Day & $\mathbf{k}$ & $\mathbf{t}_{\mathbf{5 0}}$ & $\mathbf{R}^{\mathbf{2}}$ & Day & K & \multicolumn{1}{c}{ Reference } \\
\hline R. mucronata & 60 & 0.035 & 19 & 0.79 & 47 & 0.10 & Bosire et al. 2005 \\
R. apiculata & 60 & 0.040 & 17 & 0.78 & 43 & 0.016 & Ashton et al. 1999 \\
S. alba & 60 & 0.041 & 17 & 0.77 & 31 & 0.16 & Bosire et al. 2005 \\
R. stylosa & 60 & 0.028 & 24 & 0.88 & 63 & 0.010 & Irma 2010 \\
A.marina & 60 & 0.065 & 10 & 0.96 & 21 & 0.014 & Fernando and Bandeira 2009 \\
\hline
\end{tabular}


Symmetric plot

(axes F1 and F2: 99,35\%)

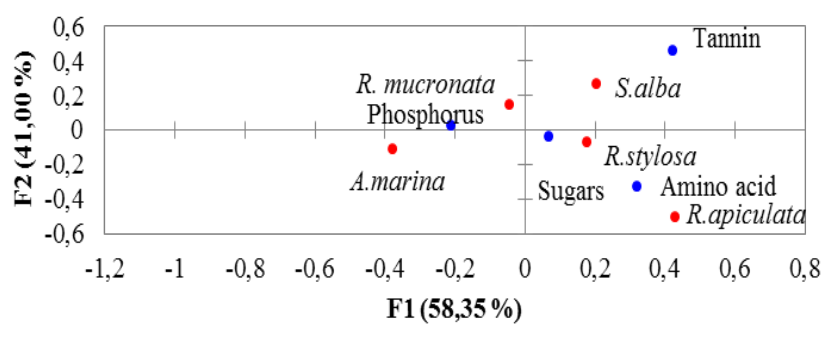

- Columns • Rows

Figure 3. The correlation between content of metabolites and the decomposition rates of decomposition of leaves across five mangrove species based on Correspondence Analysis (CA). F1 is the first axis of the Correspondence Analysis and F2 is the second axis

\section{The relationship between decomposition rate and the metabolites content of mangrove leaves}

The leaf dry weight measurements from which decomposition rates were calculated were taken on three occasions; day 0 , day 30 , and day 60 . The measurement of secondary metabolite content of the mangrove leaves was conducted on a single occasion at the beginning, before the decomposition process began. Figure 3 shows the relationship between rate of decomposition and secondary metabolite contents in the mangrove leaves as depicted on the first two axes of a Correspondence Analysis plot. The result of the Correspondence Analysis showed that $71.5 \%$ of the total variation was accounted for by the first axis (F1) and $25.6 \%$ was accounted for by the second axis (F2), the two axes together accounting for $97.1 \%$ of the total variation. The Correspondence Analysis suggested that there was a close relationship between particular secondary metabolites and the rate of leaf decomposition of the different mangrove species. Tannin content was inversely proportional to the decomposition rate (-0.615) and phosphorus content was directly proportional to the decomposition rate $(0.51)$. It showed that the lower the content of tannin is, the faster the decomposing rate will be.

\section{Discussion}

This research was designed to determine the amino acid, tannin, total sugar, and phosphorus contents of leaves of the mangrove species Rhizophora mucronata, Rhizophora apiculata, Sonneratia alba, Rhizophora stylosa, and Avicennia marina, and to see if these chemical constituents influenced the rate at which the leaves decomposed in a controlled experiment on the Pasar Banggi coast of Rembang in Central Java. In this study, the main metabolites that were found to apparently influence leaf decomposition rate were tannin and phosphorus. In other studies, high concentration of tannin has been found to play a role in inhibiting the activity of detritivores and microbial decomposers (Robertson 1988). Differences in leaf tannin concentration have been reported to lead to differences in decomposition rate and microbial activity (Ellison and Farnsworth 1997; Tam et al. 1998). The rate of leaf decomposition is influenced by leaching of watersoluble compounds such as tannins, amino acids, and sugar (Rajendran and Kathiresan 2000). A slower rate of decomposition results from higher concentrations of lignin and hydrolyzed-tannins.

In our study, leaves of $A$. marina on the Pasar Banggi coast, of Rembang, Central Java had a faster rate of decomposition than leaves of the other mangrove species assessed. This was also reported by Robertson (1988) who found in Australia that A. marina contained lower levels of hydrolyzed-tannin and degraded faster than $R$. stylosa. In India, Rajendran and Kathiresan (2000) reported that the tannin concentration declined to $63.3 \%$ in $R$. apiculata and $38.8 \%$ in A. marina after 40 days of decomposition. Similarly, Rajendran and Kathiresan (2007) reported lower tannin concentration in A. marina than in $R$. apiculata during the first three weeks of decomposing, after which, the concentration of tannin was similar in both species. Cundell et al. (1979) also noted declining tannin concentration after 27 days of the decomposing process.

Steinke et al. (1993) reported that in the early stages of leaf decomposition, soluble organic compounds such as sugars are washed out of the leaves, while more durable materials, represented in the dry-weight of the leaves, break down at a slower rate (Steinke et al. 1990). The degradation and decomposition of mangrove leaves can be affected by the frequency of sea flux and reflux (Dick and Osunkoya 2000; Mfilinge et al. 2002; Bosire et al. 2005). The level of decomposition is higher in the sub-tidal area than in the intertidal area, as a result of sea water submersion and washing away of materials. In our study, leaves of $A$. marina decomposed faster than leaves of $R$. mucronata. Differences in the morphology and texture of the leaves could be factors along with chemical constituents such as tannins in the differences in decomposition rate (Alongi et al. 2000). Damage to ecosystems of mangrove could cause differences in rates of mangrove decomposition, with rollon effects on microbiological activity, aerobic condition of the bottom sediments and on dependent fauna communities (Clough et al. 2000; Morrisey et al. 2003; Ye et al. 2013). Our research revealed that the decomposition of $R$. mucronata, $R$. stylosa, and $R$. apiculata leaves required a longer time than leaves of $A$. marina a result that confirmed the findings of Wafar et al. (1997) and Hoosain et al. (2014).

Robertson (1998) reported that the decomposition of mangrove leaf litter in tropical area required 40 days to decompose $50 \%$ of the dry matter. Ashton et al. (1999) reported a half-life of 43 days for leaves of $R$. apiculata in a conservation mangrove forest on the Malaysian Peninsula. When the decomposition process is slow the nutrient loss from the leaves and consequent nutrient enrichment of the environment declines (Lacerda et al. 1986).

The decomposition rate $(\mathrm{k})$ on the Pasar Banggi coast of Rembang ranged between 0.028 and 0.079 in our study. The value for $\mathrm{k}$ of $R$. stylosa (0.079) was higher than the $\mathrm{k}$ value for $S$. alba (0.028). In general, the k values in our 
study can be regarded as high, since according to the classification of Ananda et al. (2008), values of $k>0.01$ reflect fast decaying leaves, values of $\mathrm{k}$ between 0.005 and 0.01 are obtained from leaves that decay at medium rates, and slow decaying leaves have values of $\mathrm{k}<0.005$.

The tannin content of mangroves plays a role in several ecological processes (Hernes et al. 2001, Kraus et al. 2003). Tannins have an impact on growth, development, and reproduction, and act as defensive agents against biotic and abiotic pressures (Achakzai et al. 2009). High tannin levels can slow down the cycling of nutrients (Madritch and Lindroth 2015). Tannins leached from the leaves during initial breakdown eventually decompose and are transformed by biotic and abiotic processes in the watery environment (Hattenschwiler and Vitousek 2000; Kraus et al. 2003; Maie et al. 2008).

In conclusion, the rate of decomposition of mangrove leaves in our study ranked from the highest to lowest the lowest rate was as follows: A. marina $>S$. alba $>R$. mucronata $>R$. apiculata $>R$. stylosa. The fastest decomposition was $A$. marina $(\mathrm{k}=0.065)$, and the slowest one was $R$. stylosa $(\mathrm{k}=0.0282)$. The relationship of the faster decomposition of mangrove leaves affected by the high phosphorus and the low tannin in A. marina.

\section{ACKNOWLEDGEMENTS}

The authors are thankful to the Ministry of Research and Technology of Higher Education, Indonesia for providing a fellowship in pursuit of a Ph.D. degree.

\section{REFERENCES}

Achakzai AKK, Achakzai P, Masood A, Kayani SA, Tareen RB. 2009. Response of plant parts and age on the distribution of secondary metabolites on plants found in Quetta park. J Bot 41 (5): 2129-2135.

Alongi DM, Tirendi F, Clough BF. 2000. Below-ground decomposition of organic matter in forests of the mangroves Rhizophora stylosa and Avicennia marina along the arid coast of Western Australia. Aquat Bot 68: 97-122.

Ananda K, Sridhar KR, Raviraja NS, Ba'rlocher F. 2008. Breakdown of fresh and dried Rhizophora mucronata leaves in a mangrove of Southwest India. Wetlands Ecol Manag 16: 1-9.

Anderson JM, Ingram JSI. 1989. Tropical Soil Biology, and Fertility: A Handbook of Methods. 2nd ed. CAB International, Wallingford, United Kingdom.

Ariyanto D, Bengen DG, Prartono T, Wardiatno Y. 2018. The association of Cassidula nucleus (Gmelin 1791) and Cassidula angulifera (Petit 1841) with mangrove in Banggi Coast, Central Java, Indonesia AACL Bioflux 11 (2): 348-361.

Ashton EC, Hogarth PJ, Ormond R. 1999. Breakdown of mangrove leaf litter in a managed mangrove forest in Peninsular Malaysia. Hydrobiologia 413: 77-88.

Balakrishnan S, Srinivasan M, Santhanam P. 2016. Interactions of nutrients, plant growth and herbivory in a Parangipettai mangrove ecosystem of the Vellar estuary, Southeast coast of India. Reg Stud Mar Sci. 5: 19-26.

Bosire JO, Dahdouh Guebas F, Kario JG, Kazungu J, Dehairs F, Koedam N. 2005. Litter degradation and CN dynamics in reforested mangrove plantations at Gazi Bay, Kenya. Biol Conserv 126: 287295.

Boulton AJ, Boon PI. 1991. A review of the methodology used to measure leaf litter decomposition in lotic environments: time to turn over an old leaf? Australian. J Mar Freshwater Res 42: 1-43.
Castanho T, de Oliveira AA. 2008. Relative effect of litter quality, forest type and their interaction on leaf decomposition in south-east Brazilian forests. J Trop Ecol 24: 149-156.

Clough B, Tan DT, Phuong, DX, Buu, DC. 2000. Canopy leaf area index and litterfall in stands of the mangrove Rhizophora apiculata of different age in the Mekong Delta, Vietnam. Aquat Bot 66: 311-320.

Covelo F, Ávila JM, Gallardo A. 2011. Temporal changes in the spatial pattern of leaf traits in a Quercus robur population. Ann For Sci 68: 453-460.

Cundell AM, Mueller WC, Traxler RW. 1976. The morphology and ultrastructure of a Penicillium sp. grown on peptone and nhexadecane. Appl Env Microbiol 31: 408-414

Davis SE, Coronado-Molina C, Childers DL, Day JW. 2003. Temporally dependent $\mathrm{C}, \mathrm{N}$, and $\mathrm{P}$ dynamics associated with the decay of Rhizophora mangle L. leaf litter in oligotrophic mangrove wetlands of the Southern Everglades. Aquat Bot 75: 199-215.

Dick TM, Osunkoya OO. 2000. Influence of tidal restriction floodgates on decomposition of mangrove litter. Aquat Bot 68: 273-280.

Dubois M, Gilles KA, Hamilton JK, Rebers PA, Smith F. 1956. Colorimetric method for determination of sugars and related substances. Anal Chem 28: 350-356.

Ellison AM, Farnsworth EJ. 1997. Simulated sea level change alters anatomy, physiology, growth, and reproduction of red mangrove (Rhizophora mangle L.). Oecology 112: 435-446.

Fernando SMC, Bandeira SO. 2009. Litter fall and decomposition of mangrove species Avicennia marina and Rhizophora mucronata in Maputo Bay, Mozambique. W Ocean J Mar Sci 8 ( 2): 173 -182.

Fukushima Y, Sasamoto H, Baba S, Ashihara H. 1997. The effect of salt stress on the catabolism of sugars in leaves and roots of a mangrove plant, Avicennia marina. J Biosciences 52: 3-4.

Gong WK, Ong JE. 1990. Plant biomass and nutrient flux in a managed mangrove forest in Malaysia. Estuar Coast Shelf Sci 31: 519-530.

Hagerman A, Butler L. 1978. Protein precipitation method for quantitative determination of tannins. Food Chem 26: 809-812.

Hattenschwiler S, Vitousek PM. 2000. The role of polyphenols in terrestrial ecosystem nutrient cycling. Trend Ecol Evol 15: 238-243.

Hernes PJ, Benner R, Cowie GL, Goni MA, Bergamaschi BA, Hedges JI. 2001. Tannin diagenesis in mangrove leaves from a tropical estuary: A novel molecular approach. Geochimica et Cosmochimica. Acta 65: 3109-3122.

Hernes PJ, and Hedges JI. 2004. Tannin signatures of barks, needles, leaves, cones, and wood at the molecular level. Geochim. Cosmochim. Acta 68: 1293-1307.

Hessen DO, Ågren GI, Anderson TR, Elser JJ, De Ruiter PC. 2004. Carbon sequestration in ecosystems: the role of stoichiometry. Ecol 85: 1179-92.

Holguin G, Vazquez P, Bashan Y. 2001. The role of sediment microorganisms in the productivity, conservation, and rehabilitation of mangrove ecosystems: an overview. Biol Fertil Soils 33: 265-78

Hoosain M, Siddique MRH, Abdullah SMR, Sanjoy S, Chandra DG, Rahman MS, Limon SH. 2014. Nutrient dynamics associated with leaching and microbial decomposition of four abundant mangrove species leaf litter of the Sundarbans Bangladesh. Wetlands 34: 439448.

Imgraben S, Dittmann S. 2008. Leaf litter dynamics and litter consumption in two temperate South Australian mangrove forests. J Sea Res 59: 83-93.

Irma D. 2010. Litter decomposition of Rhizophora stylosa in Sabang-Weh Island, Aceh, Indonesia; evidence from mass loss and nutrients. Biodiversitas 11 ( 3): 139-144.

Kandil FE, Grace MH, Seigler DS, Cheeseman JM. 2004. Polyphenolics in Rhizophora mangle L. leaves and their changes during leaf development and senescence. Trees 18: 518-528.

Kraus TEC. Dahlgren RA, Zasoski RJ. 2003. Tannin in nutrient dynamic of forest ecosystem A review. Plant Soil 256: 41-66

Kristensen E, Bouillon S, Dittmar T, Marchand C. 2008. Organic carbon dynamics in mangrove ecosystems: a review. Aquat Bot 89: 201-219.

Kursar TA, Coley PD. 1991. Nitrogen content and expansion rate of young leaves of rainforest species: Implications for herbivory. Biotropica 23: 141-150.

Lacerda LD, Jose DV, Rezende CE, Francisco MCF, Wasserman JC, Martins JC. 1986. Leaf chemical characteristics affecting herbivory in a New World mangrove forest. Biotropica 18 (4): 350-355.

Lin P, Wang W. 2001. Changes in the leaf composition, leaf mass and leaf area during leaf senescence in three species of mangroves. Ecol Eng 16: 415-424. 
Lin YM, Liu JW, Xiang P, Lin P, Ye GF, Sternberg LD. 2006. Tannin dynamics of propagules and leaves of Kandelia candel and Bruguiera gymnorrhiza in the Jiulong River Estuary, Fujian, China. Biogeochemistry 78: 343-359.

Madritch MD, Lindroth RL. 2015. Condensed tannins increase nitrogen recovery by trees following insect defoliation. New Phytologist 208: $410-420$

Maie N, Pisani O, Jaffe R. 2008. Mangrove tannins in the aquatic ecosystem: Their fate and possible influence on

dissolved organic carbon and nitrogen cycling. Limnology Oceanography 53 (1): 160-171.

Mfilinge P, Atta N, Tsuchiya M. 2002. Nutrient dynamics and leaf litter decomposition in a subtropical mangrove forest at Oura Bay Okinawa, Japan. Trees 16: 172-180.

Mfilinge PL, Meziane T, Bachok Z, Tsuchiya M. 2005. Litter dynamics and particulate organic matter outwelling from a subtropical mangrove in Okinawa Island. South Japan. Estuar Coast Shelf S 63 301-313.

Moore S, Stein WH. 1948. Photometric ninhydrin method for use in the chromatography of amino acids. J Biol Chem 176: 367-387.

Morrisey D, Skilleter G, Ellis J, Burns B, Kemp C, Burt K. 2003. Differences in benthic fauna and sediment among mangrove (Avicennia marina var. australasica) stands of different ages in New Zealand. Estuar Coast Shelf Sci 56: 581-592.

Norris MD, Avis PG, Reich PB, Hobbie SE. 2012. Positive feedbacks between decomposition and soil nitrogen availability along fertility gradients. Plant Soil 367: 347-61.

Northup RR, Dahlgren RA, Mccoll JG. 1998. Polyphenols as regulators of plant-litter-soil interactions in Northern California's pygmy forest: A positive feedback? Biogeochemistry 42: 189-220.

Popp M, Larher F, Weigel P. 1983. Chemical composition of Australian mangroves III. Free amino acids, total methylated onium compounds, and total nitrogen. Zeitschrift für Pflanzenphysiologie 114: 15-25.

Rajendran N, Kathiresan K. 2000. Biochemical changes in decomposing leaves of mangroves. Chem Ecol 17: 91-102.

Rajendran N, Kathiresan K. 2007. Microbial flora associated with submerged mangrove leaf litter in India. Int Trop Biol 55 (2): 393400
Ralston L, Subramanian S, Matsuno M, Yu O. 2005. Partial reconstruction of flavonoid and isoflavonoid biosynthesis in yeast using soybean Type I and Type II chalcone isomerases. Plant Physiol 137: 13751388

Ravi AV, Kathiresan K. 1990. Seasonal variation in gallotannin from mangrove. Indian Journal Mar Sci 19: 224-225.

Robertson AI. 1988. Decomposition of mangrove leaf litter in tropical mangrove forest. Hydrobiologia 332: 93-98.

Steinke T, Barnabas A, Somaru R. 1990. Structural changes and associated microbial activity accompanying decomposition of mangrove leaves in Mgeni Estuary. S Afr J Bot 56: 39-48.

Steinke T, Holland A, Singh Y. 1993. Leaching losses during decomposition of mangrove leaf litter. S Afr J Bot 59: 21-25.

Suh SS, Hwang J, Park M, Park HS, Taek-Kyun Lee TK. 2014. Phenol content, antioxidant and tyrosinase inhibitory activity of mangrove plants in Micronesia. Asian Pac J Trop Med 7 (7): 531-535.

Takemura T, Hanagata N, Sugihara K, Baba S, Karube I, Dubinsky Z. 2000. Physiological and biochemical responses to salt stress in the mangrove, Bruguiera gymnorrhiza. Aquat Bot 68: 15-28.

Tam NFY, Wong YS. 1998. Variations of soil nutrient and organic matter content in the subtropical mangrove ecosystem. Water Air Soil Poll 103: $245-261$.

Telave AB. 2015. Ecophysiological studies on Sonneratia L. from the coast of Maharashtra. Indian Journal of Geo -Mar Sci. 44 (8): 12391244.

Wafar S, Untawale AG, Wafar M. 1997. Litter fall and energy flux in a mangrove ecosystem. Estuar Coast Shelf Sci 44: 111-124.

Wardle DA, Bardgett RD, Klironomos RN, Setala H, van der Putten WH, Wall D. 2004. Ecological linkages between above ground and below ground biota. Sci 304: 1629-1633.

Yan L, Guizhu C. 2007. Physiological adaptability of three mangrove species to salt stress. Acta Ecol Sinica. 27 (6): 2208-2214.

Ye Y, Chen YP, Chen GC. 2013. Litter production and litter elemental composition in two rehabilitated Kandelia obovata mangrove forests in Jiulongjiang Estuary, China. Mar Environ Res 83: 63-72.

Zhou HC, Wei Sd, Zeng Q, Zhang LH, Tam NF, Lin YM. 2010. Nutrient and caloric dynamics in Avicennia marina leaves at different developmental and decay stages in Zhangjiang River Estuary, China. Estuar Coast Shelf Sci 87: 21-26. 